\title{
Integrated method for production of hydrophobin-type protein and milk-clotting enzyme using Coprinus lagopides mushroom
}

\author{
Boris Kolesnikov ${ }^{1, *}$, Eugene Vorobeychikov ${ }^{1}$, and Mark Shamtsyan ${ }^{1}$ \\ ${ }^{1}$ St. Petersburg State Institute of Technology (Technical University), Moskovsky prospect, 26, \\ 190013, St. Petersburg, Russia
}

\begin{abstract}
Submerged culture of the mushroom Coprinus lagopides was studied as a source of surfactant proteins and milk-clotting enzyme. Low molecular fungal proteins called hydrophobins exhibit unusual surfactant properties. They are able to self-assemble at the interface and to change the surface properties. Emulsions formed by these low-molecular proteins are very stable and can be used as stabilizers for edible foams and emulsions. By their taste and mouth feel air emulsions of hydrophobins resemble fats and can be used to substitute up to $50 \%$ of them in large variety of foods. Despite the fact that hydrophobins have great application potential, however, the possibility of their use is currently very limited due to their insufficient output. Screening for new efficient producers of hydrophobins and development of new integrated methods of their production along with other valuable materials can help to overcome this problem. $\mathrm{n}$ this paper, we propose a novel producer of highly active surfactant proteins and a novel integrated method of obtaining as a result of a single fermentation surfactant proteins and milk-clotting enzyme.
\end{abstract}

\section{Introduction}

Mushrooms are a source of a vast variety of biologically active substances. Kingdom fungi includes variously estimated up to 250 thousand species, however, only a small part of them is studied as the potential source of different valuable compounds. In the mid- 80 s special proteins called hydrophobins were found during the search for genes expressed in the formation of aerial hyphae on the mycelium of the fungus Schizophyllum commune [1]. These proteins possess interesting physical properties and are a promising target for the study and application in various fields. A unique feature of hydrophobins is that they selfassemble into amphipathic membranes and converting the properties of contact surfaces. A very important part of this is that hydrophobins assemble on an interface between a hydrophobic and hydrophilic material (e.g. water and air).

Hydrophobins have been identified as conferring a high viscoelasticity nature to the surfaces of air bubbles, leading to excellent stability against disproportionation and

\footnotetext{
*Corresponding author: kalelovo@mail.ru
} 
coalescence [2]. Hydrophobins also have an ability to stabilise emulsions [3]. The physical properties of hydrophobins make them suitable for the production of tri-phasic (air/oil/water) emulsions [4].

According to the structure and distribution of hydrophilic and hydrophobic amino acid residues hydrophobins can be divided into two classes, I and II [5]. Aggregates formed by these two classes differ in their solubility, and morphology.

The membrane formed of class I hydrophobins, has an extremely low solubility and can only be dissociated by highly concentrated acids (such as formic acid or pure trifluoroacetic acid). Complexes formed of class II hydrophobins are less stable and can be easily dissolved in a $60 \%$ ethanol solution or $2 \%$ SDS. In this regard, methods of isolation and purification of different classes of hydrophobins are quite different [6,7].

The range of intended applications of hydrophobins include their use as indicators in beer gashing [8], surface coatings [9-11], the agents for the immobilization [12,13], and others. One of the most promising applications of hydrophobins is their use as stabilizers for edible foams and emulsions [14,15]. Moreover, emulsions formed by these lowmolecular proteins by their taste and mouth feel resemble fats and can be used to substitute them in large variety of foods.

Despite the fact that hydrophobins have great application potential, however, the possibility of their use is currently very limited. This is due to the fact that hydrophobins output is insufficient for testing of their wide use, and large-scale production of hydrophobins is not existing yet. In this regard, the actual problem is to find new producers of hydrophobins, as well as to develop new technologies for isolation and purification of this compounds, which would provide the highest product yield and significantly cheaper production process. One possible way to increase the efficiency of the production of surfactant proteins of fungi is to develop an integrated process for their preparation together with other valuable products. In particular, because mushrooms have rich enzymatic complexes, it is appropriate to develop an integrated process for the preparation of surfactant proteins in conjunction with the production of enzyme preparations.

We have previously reported about Coprinus lagopides mushroom, as a producer of highly active milk-clotting enzyme [16, 17]. In cheese making rennet enzymes are traditionally used. However, their high cost makes it relevant the question of their substitution with new sources of milk-clotting enzymes.

The main requirement for milk-clotting preparations, which enable the production of high-quality cheeses, is high level of milk-clotting activity in combination with the high ratio of specific milk-clotting activity to the total proteolytic activity. As the enzyme produced by Coprinus lagopides meets all the requirements for milk-clotting enzymes, this mushroom can be considered as a source of simultainious production of class I hydrophobins and milk-clotting enzyme.

Thus, the aim of our work was to study the submerged culture of Coprinus lagopides as a source of surfactant proteins, as well as to develop a comprehensive method for their isolation and purification and a novel method of combined production of hydrophobin-type proteins and enzymes milk-clotting enzyme.

\section{Material and methods}

\subsection{Submerged cultivation}

The object of our study was the culture of mushroom Coprinus lagopides. P. Karst from the collection of basidiomycetes of St. Petersburg State Institute of technology (Technical University). 
Initial cultures were cultivated under submerged conditions in flasks at a temperature of $28 \mathrm{C}$ for 7-10 days on the rotary shaker (IR-1LT, Labtech, Moscow, Russia) using semisynthetic medium containing $(\mathrm{g} / \mathrm{L})$ : glucose 10 ; peptone 2.5; $\mathrm{KH}_{2} \mathrm{PO}_{4} 0.6 ; \mathrm{K}_{2} \mathrm{HPO}_{4} 0.4$; $\mathrm{CaCl}_{2}$ 0.05; $\mathrm{NaCl} 0.5$; yeast extract 2.0; $\mathrm{pH}$ of the media before sterilization was 5.8-6.0. Also the influence of different levels of glucose (from 5 to $40 \mathrm{~g} / \mathrm{L}$ ) and peptone (from 1 to 4 $\mathrm{g} / \mathrm{L}$ ) on the production of hydrophobin-type proteins and milk-clotting enzyme were studied.

To determine the optimal ratios of Glucose and peptone in nutritive medium for Coprinus lagopides mushroom for increasing of the syntheses of hydrophobin-type proteins $(\mathrm{Y} 1, \mathrm{mg} / \mathrm{mL})$ and milk-clotting activity $(\mathrm{MCA}, \mathrm{Y} 2, \mathrm{U} / \mathrm{mL})$ a method of multiple regression analysis was used $[18,19]$. In the experiment, the glucose $(\mathrm{X} 1 \mathrm{mg} / \mathrm{mL})$ and peptone $(\mathrm{X} 2$ $\mathrm{mg} / \mathrm{mL}$ ) concentrations in the culture medium were varied at three levels: a minimum (-), mean $(0)$ and maximum (+). The levels of variation for these factors were selected based on economic feasibility and analysis of preliminary studies. The experimental results were processed using a statistical software package «Statgraphics CENTURION XVI».

After separation of mycelium by filtration from culture broth, mycelium and native liquid were used for farther studies.

The concentration of oxygen in the medium has a great effect on the biosynthesis of proteins by fungi [19]. Therefore, synthesis of hydrophobins can depend on a degree of aeration of the medium.

To determine the effect of aeration of the medium on the synthesis of surfactant proteins and milk-clotting activity mushroom was cultured in $750 \mathrm{~mL}$ Erlenmeyer flasks with different quantity of liquid medium - 50, 100 and $150 \mathrm{~mL}$. Aeration rate was determined by the sulfite method [20]

The dissolution rate of oxygen in the flasks was: with $50 \mathrm{~mL}$ medium $4.4 \mathrm{~g} \mathrm{O}_{2} / \mathrm{L}^{*} \mathrm{~h}$, with $100 \mathrm{~mL}$ of medium $3.0 \mathrm{~g} \mathrm{O}_{2} / \mathrm{L}^{*} \mathrm{~h}$, with $150 \mathrm{~mL}$ of medium $1.8 \mathrm{~g} \mathrm{O}_{2} / \mathrm{L}^{*} \mathrm{~h}$.

\subsection{Extraction of surfactant proteins}

Biomass of fungi can serve a source of hydrophobins [21-25]. Mycelia biomass obtained from submerged cultivation was subjected to successive freezing and defrosting with subsequent processing using ultrasonic disintegrator (Prointeh - Bio, Russia) in order to break the cell walls to achieve higher yield of the studied proteins. The homogenate was centrifuged at $4500 \mathrm{~g}$.

Hydrophobins of basidiomycetes, of which is the Coprinus lagopides mushroom, belong to Class I, and form agglomerates, which are soluble only in strong acids [26].

Proteins from mycelia were removed by extraction with $1 \%$ SDS solution at $100^{\circ} \mathrm{C}$ for 10 min. After that biomass was washed with water and extracted with $99 \%$ trifluoroacetlc acid (TFA) for 3 hours to break up agglomerates formed by class I hydrophobins. TFA was removed by evaporation under a stream of air at room temperature.

TFA treated extract was dissolved in $70 \%$ ethanol, and then centrifuged at $4500 \mathrm{~g}$ to remove insoluble precipitate in ethanol. Ethanol was than evaporated on a vacuum rotary evaporator at $40^{\circ} \mathrm{C}$. The resulting protein aqueous solution was freeze dried. The protein concentration in the resultant extract was determined by the Lowry method [27].

\subsection{Analysis of the extracts}

Chromatographic methods were used for the analysis and purification of the resulting extract. Since in our work we deal with surfactant proteins, inverted phase HPLC has been used for their separation. 
For protein analysis a 5-micron column size $250 \times 4.6 \mathrm{~mm}$ SupelcoSil C8 (SGE Analytical Science (Australia)). As the stationary phase used was silica grafted with groups C8.

Injected sample volume was $20 \mu \mathrm{L}$, and the mobile phase consisted of $0.1 \%$ trifluoroacetic acid (TFA) and $50 \%$ (by volume) acetonitrile, $\mathrm{pH}=3.0$. Flow rate $\quad 0.8 \mathrm{~mL}$ / min. UV absorption of the eluant was observed at $280 \mathrm{~nm}$ and $254 \mathrm{~nm}$. According to the obtained chromatograms the presence of peaks and their compliance with those described in the literature for the desired surfactant proteins were defined.

To determine the molecular weight of the protein was used disc electrophoresis method in polyacrylamide gel electrophoresis (PAGE) according to the method of Laemmli [28].

Stacking gel contained $4 \%$ polyacrylamide and the separating gel $7.5 \%$. The gel was polymerized in the glass tubes from the kit "Apparatus for electrophoresis" model 73 production Reanal (Hungary). As an indicator front mobility during electrophoresis, $0.1 \%$ bromophenol blue dye solution was used, which was applied together with the samples in each tube with gel in an amount of $0.01 \mathrm{~mL}$

The procedure of the first half hour of electrophoresis was carried out at a current 0.5 $\mathrm{mA}$ per one tube, then at $2 \mathrm{~mA}$ per tube until the end of the separation process. The amount of protein per one tube does not exceed $250 \mathrm{mg}$. The insulin, which has a molecular weight of about $6 \mathrm{kD}$ was used as a standard protein. After electrophoresis the samples were compared with the control and the molecular weight of the surfactant protein was determined.

\subsection{Assessing the impact of the resulting product to foam stability}

To evaluate surface activity of obtained extracts we tested the effects of obtained proteins on the foam stability. It is known that hydrophobins cause high foam stability, even at extremely low concentrations.

For comparison, as a control was used Sodium caseinate. As a solution thickener, xanthan was used.

To $20 \mathrm{~mL}$ of a $0.5 \%$ solution of xanthan gum dried protein preparation obtained after removal of the extractant (ethyl alcohol) was added. As a control, $20 \mathrm{~mL} 0.5 \%$ xanthan gum solution containing $0.01 \%$ sodium caseinate was taken. The test and control samples were foamed for 20 seconds in a rotary foamer. Further, the resulting foam volume was measured immediately after foaming and weekly for 2 months.

\subsection{Determination of milk-clotting and total proteolytic activities}

The level of the milk-clotting activity (MCA) was determined according to the method of Kawai-Mukai [29]. The method for determination of the milk-clotting activity (MCA) is based on the determination of time, necessary for clot formation. Fresh commercial milk ( $25 \mathrm{~g} / \mathrm{L}$ fat) with addition of $\mathrm{CaCl}_{2}(150 \mathrm{mg} / \mathrm{L}), \mathrm{pH} 6.0$ was used as a substrate. One unit of MCA was defined as the amount of enzyme, required to clot $100 \mathrm{~mL}$ of milk within $40 \mathrm{~min}$ at $35^{\circ} \mathrm{C}$ :

$$
M C A=40 * 100 * C / 2 P \text { Units } / m L
$$

where $C$ - dilution coefficient of native liquid or enzyme preparation,

$P$ - period of time (min), during which a dense milk curd forms as a result of adding enzyme or native liquid, 
40 - average time (min), during which $100 \mathrm{~mL}$ of milk is curdled, 2 e volume (mL) of added enzyme or native liquid.

The level of the total proteolytic activity was determined according to the Russian state standard (GOST 20264.2 e 88) method, based on hydrolyses of casein proteins. This method for determination of the general proteolytic activity (PA) is based on hydrolysis of the proteins of casein by the studied preparation and subsequent inactivation of enzyme and precipitation of the non-hydrolyzed protein by trichloroacetic acid (TCA). One unit of proteolytic activity was defined as the amount of enzyme, required to convert casein into non-TCA-precipitable form within $1 \mathrm{~min}$ at $30^{\circ} \mathrm{C}$ in the quantity, which corresponds to 1 $\mathrm{mmol}$ of tyrosine. The activity is expressed in $\mathrm{U} / \mathrm{mg}$ of protein.

\subsection{Purification and concentration of enzyme}

An ultrafiltration method (membranes "MIFIL-PA-20" (IPhOCh, Minsk, Belarus) with a limit of nominal molecular weight retention of membranes of $20 \mathrm{kDa}$ ) was used to purify and concentrate enzymes. Ultrafiltrate was lyophilized to obtain powder preparation. Dried enzyme preparation for further studies was used dissolved in $0.01 \mathrm{~mol} / \mathrm{L} \mathrm{Na}$-phosphate buffer ( $\mathrm{pH}=6.8)$. When determining the kinetic constants, the concentration of milk-clotting enzyme preparation in samples with different concentrations of the substrate (milk) was constant and was $27 \mathrm{mg} / \mathrm{mL}$, corresponding to $50 \mathrm{U} / \mathrm{mL}$.

Purified and concentrated liquid was freeze-dried.

\section{Result and discussion}

Initialy Coprinus lagopides was cultured for 7 days at the $100 \mathrm{~mL}$ culture medium. Protein concentration obtained in mycellia extracts was $3.75 \mathrm{mg} / \mathrm{g}$ dry biomass, and from the native liquid of culture medium was at $13.5 \mathrm{U} / \mathrm{mL}$.

Table 1. Experimental plan and the results describing the accumulation of the protein (Y1) in the extract from the biomass and MCA activity level (Y2) in the native liquid of Coprinus lagopides for different factor values $(\mathrm{Cg}, \mathrm{Cp})$.

\begin{tabular}{|c|c|c|c|c|c|c|}
\hline \multirow[t]{2}{*}{$\begin{array}{l}\text { No of the } \\
\text { experiment }\end{array}$} & \multicolumn{2}{|c|}{$\begin{array}{c}\text { Factor variation } \\
\text { levels }\end{array}$} & \multicolumn{2}{|c|}{$\begin{array}{l}\text { Absolute values of } \\
\text { the factors, } g / 1\end{array}$} & \multirow{2}{*}{$\begin{array}{c}\text { Protein } \\
\text { concentration } \\
\mathrm{Y}_{1}, \mathrm{mg} / \mathrm{ml}\end{array}$} & \multirow{2}{*}{$\begin{array}{c}\mathrm{MCA}, \\
\mathrm{Y}_{2}, \\
\mathrm{U} / \mathrm{ml}\end{array}$} \\
\hline & $\mathrm{X}_{1}$ & $\mathrm{X}_{2}$ & $\mathrm{Cg}$ & $\mathrm{Cp}$ & & \\
\hline 1 & 0 & + & 15,00 & 4,00 & 39,99 & 12,1 \\
\hline 2 & + & + & 20,00 & 4,00 & 48,98 & 10,7 \\
\hline 3 & + & 0 & 20,00 & 2,50 & 38,50 & 20,1 \\
\hline 4 & 0 & 0 & 15,00 & 2,50 & 36,72 & 17,4 \\
\hline 5 & - & + & 10,00 & 4,00 & 20,26 & 5,7 \\
\hline 6 & - & - & 10,00 & 1,00 & 13,55 & 18,0 \\
\hline 7 & - & 0 & 10,00 & 2,50 & 17,25 & 13,3 \\
\hline 8 & + & - & 20,00 & 1,00 & 29,40 & 25,8 \\
\hline 9 & 0 & - & 15,00 & 1,00 & 30,78 & 23,4 \\
\hline
\end{tabular}

The next step was the selection of media composition to ensure the high level of biosynthesis of surfactant proteins. The biosynthesis of proteins is greatly influenced by the concentration of carbon and nitrogen sources in the medium, as well as by their ratio [18]. Therefore, we studied the effect of their content in culture medium on the biosynthesis of surfactant proteins.

Table 1 presents the planing and the results of an optimization experiment for the accumulation of the protein (Y1) in the extract from the biomass and MCA level (Y2) in 
the native liquid of Coprinus lagopides at various concentrations of glucose (X1) and peptone (X2).

Table 2 shows the parameters of the statistical characteristics of second-order polynomial models describing the dependence of the change magnitudes of (Y1) and (Y2) on the factors (X1) and (X2).

Table 2. Statistical characteristics of the parameters for plotting values of $(Y 1, Y 2)$ from the factors $(\mathrm{X} 1, \mathrm{X} 2)$.

\begin{tabular}{|c|c|c|c|c|c|c|}
\hline $\begin{array}{c}\text { Dependent } \\
\text { variables }\end{array}$ & $\begin{array}{c}\text { Model } \\
\text { parameters }\end{array}$ & $\begin{array}{c}\text { The coefficient } \\
\text { and its error }\end{array}$ & $\begin{array}{c}\text { Lower } \\
\text { limit }\end{array}$ & $\begin{array}{c}\text { Upper } \\
\text { limit }\end{array}$ & T-Criterion & $\begin{array}{c}\text { The level of } \\
\text { significance, } \mathrm{p}\end{array}$ \\
\hline \multirow{3}{*}{$\mathrm{Y} 1$} & Constant & $-67.64 \pm 9.54$ & -92.16 & -43.12 & -7.09 & 0.0009 \\
\cline { 2 - 7 } & $\mathrm{X} 1$ & $10.92 \pm 1.35$ & 7.44 & 14.39 & 8.08 & 0.0005 \\
\cline { 2 - 7 } & $\mathrm{X}^{2}$ & $-0.31 \pm 0.04$ & -0.43 & -0.19 & -7.01 & 0.0009 \\
\cline { 2 - 7 } & $\mathrm{X} 1^{*} \mathrm{X} 2$ & $0.27 \pm 0.03$ & 0.20 & 0.34 & 9.90 & 0.0002 \\
\hline \multirow{3}{*}{$\mathrm{Y} 2$} & $\mathrm{Constant}$ & $13.05 \pm 2.16$ & 7.75 & 18.34 & 6.03 & 0.0009 \\
\cline { 2 - 7 } & $\mathrm{X} 1$ & $0.65 \pm 0.13$ & 0.33 & 0.98 & 4.94 & 0.0026 \\
\cline { 2 - 7 } & $\mathrm{X}^{2}$ & $-0.85 \pm 0.08$ & -1.06 & -0.63 & -9.76 & 0.0001 \\
\hline
\end{tabular}

The statistical parameters of coefficients, represented in table 2 are indicating, that their numerical values are statistically significant $(\mathrm{p}<0,05)$. This makes possible to use these coefficients for building regression models describing the change of variables (Y1) and (Y2) from the glucose (X1 and peptone (X2)) concentrations in the nutrition medium for Coprinus lagopides in the form of Eqs. 2 and 3:

$$
\begin{gathered}
Y 1=-67.64+10.92 * C g-0.31 * X 12+0.27 * X 1 * X 2 \\
Y 1=13.05+0.65 * X 1-0.85 * X 22
\end{gathered}
$$

Analysis of variance of models (Eqs. 2 and 3) shows high coefficients of determination $\left(\mathrm{R}_{1}^{2}=98.86 ; \mathrm{R}_{2}^{2}=95.22\right)$, respectively, indicating their information capacity.

Eqs. 2 and 3 also have statistical significance $(p<0.05)$, as the value of Fisher criterion (F) for the Eq. 2 is $F=145.17>F$ cr. $=5.41$ and level of significance $(\mathrm{p}=0.0000)$, and for Eq. 3 $-F=59.82>F$ cr. $=5.14$ and level of significance $(p=0.0001)[F$ cr. - Critical value of Fisher criterion]. Graphic interpretations of the Eqs. 2 and 3 are represented in figures 1 and 2 respectively.
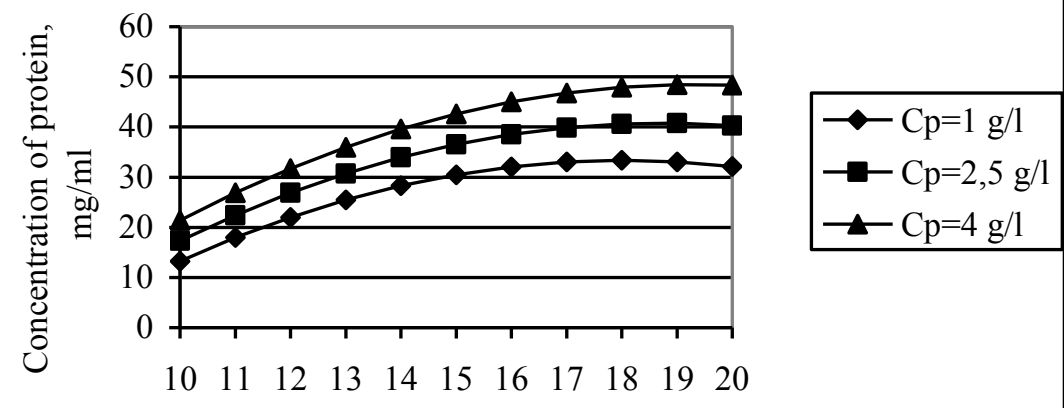

$\mathrm{Cg}, \mathrm{g} / 1$

Fig. 1. Relation of the concentration of protein (Y1) in the extract from the mycelium biomass of Coprinus lagopides from the concentration of glucose $(\mathrm{Cg})$ and peptone $(\mathrm{Cp})$ in the nutrition medium. 


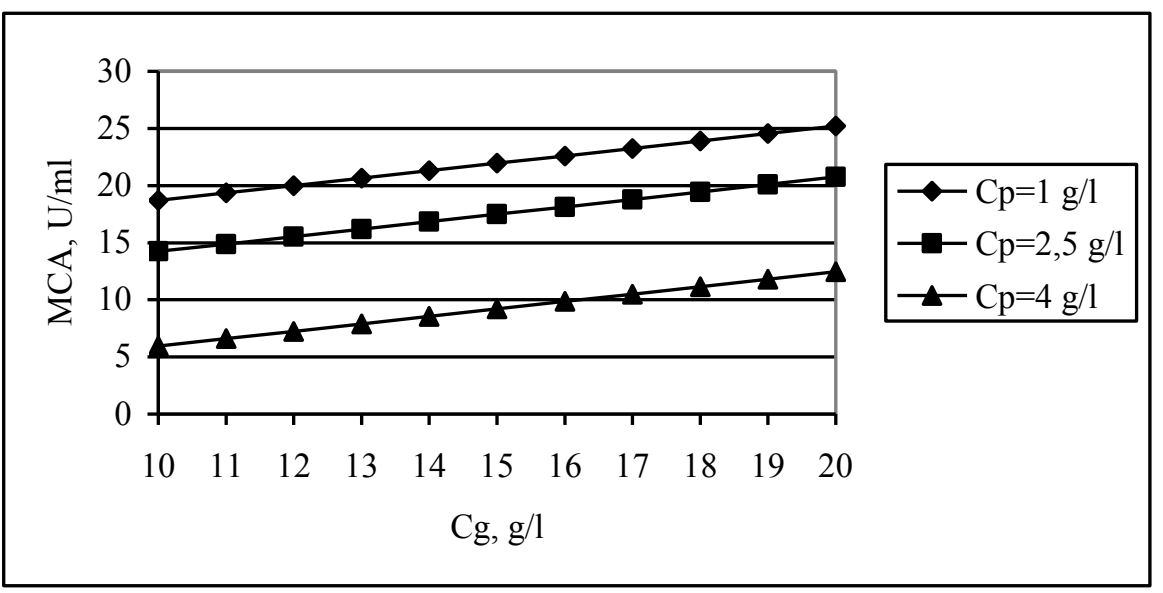

Fig. 2. Dependance of milk-clotting activity (Y1) of native liquid of Coprinus lagopides from the concentration of glucose $(\mathrm{Cg})$ and peptone $(\mathrm{Cp})$ in the nutrition medium.

Results presented in Figures 1 and 2 show, that in the conditions of the experiment, a leading factor influencing the accumulation of the protein concentration in the extract and the value of MCA in native liquid of Coprinus lagopides, is the concentration of glucose in the nutrition medium. The optimum concentration of the parameter at which the maximum values of the dependent variable Y1 were observed are in the range from 17.0 to $20.0 \mathrm{~g} / \mathrm{L}$. The value of the dependent variable of Y2 increases with the concentration of glucose and prevents clearly pronounced peaks.

Increasing the concentration of the peptone in the medium contributes to an increase in the concentration of synthesized protein (Y1), however, it reduces the level of MCA (Y1). Accordingly, for further culturing of the producer the medium with optimal concentration of glucose $(18-20 \mathrm{~g} / \mathrm{L})$ was and peptone $(2.5 \mathrm{~g} / \mathrm{L})$ was selected.

We also studied the effect of aeration on the level of synthesis of the surfactant proteins in biomass and milk-clotting activity in native liquid of cultivation. Coprinus lagopides was cultured in $750 \mathrm{~mL}$ Erlenmeyer flasks filled with different volumes of nutrient medium, which ensured different levels of aeration. The results of correlation of different levels of aeration and accumulation of biomass and biosurfactant proteins are shown in Tables 3, 4 and 5 .

Table 3. Yield of surfactant proteins and MCA at culturing of Coprinus lagopides at oxygen dissolution rate of $4.4 \mathrm{~g} / \mathrm{L} * \mathrm{~h}$.

\begin{tabular}{|c|c|c|c|c|c|c|}
\hline \multirow{2}{*}{ Parameters } & \multicolumn{7}{|c|}{ Cultivation period, days } \\
\cline { 2 - 7 } & 3 & 4 & 5 & 6 & 7 & 8 \\
\hline Biomass, g/L & $3.4 \pm 0.3$ & $4.7 \pm 0.3$ & $6.0 \pm 0.5$ & $7.7 \pm 0.6$ & $8.3 \pm 0.6$ & $8.0 \pm 0.5$ \\
\hline $\mathrm{C}_{\text {protein, }} \mathrm{mg} / \mathrm{L}$ & 8.50 & 19.41 & 38.70 & 51.74 & 57.44 & 50.72 \\
\hline $\begin{array}{c}\mathrm{C}_{\text {protein }}, \mathrm{mg} / \mathrm{g} \text { of } \\
\text { dry biomass }\end{array}$ & $2.50 \pm 0.2$ & $4.13 \pm 0.3$ & $6.45 \pm 0.3$ & $6.72 \pm 0.5$ & $6.92 \pm 0.6$ & $6.34 \pm 0.5$ \\
\hline MCA, U/mL & $5.9 \pm 0.3$ & $10.5 \pm 0.4$ & $15.1 \pm 0.3$ & $17.4 \pm 0.3$ & $19.3 \pm 0.5$ & $15.9 \pm 0.4$ \\
\hline
\end{tabular}

The results show that the highest concentration of protein from resultant biomass per gram, as well as its total yield from the unit of culture media is achieved when extracted from the mycelium of culture grown for 7 days under aeration providing oxygen solubility 
at 3.0 and $4.4 \mathrm{~g} / \mathrm{L} \mathrm{hr}$. Wherein no significant difference between these concentrations and the levels of protein produced by culturing and MCA under these conditions was observed. Therefore, it is expedient to work perform further studies with a seven day culture grown at a rate of oxygen dissolution in the medium $3 \mathrm{~g} / \mathrm{L} * \mathrm{hr}$.

Analysis of the extracts was performed by HPLC method. Matching of the peaks in the chromatogram to those of hydrophobins was determined based on literature data [26]. On the Figure 3 is the chromatogram of the extract obtained from the culture of Coprinus lagopides.

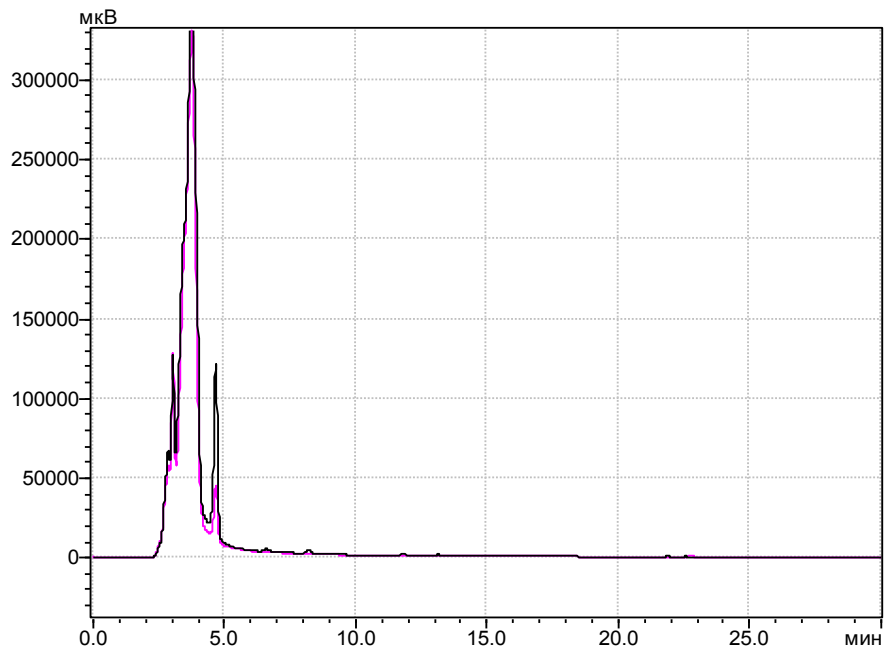

Fig. 3. Chromatogram of the extract obtained from the culture of Coprinus lagopides.

The obtained chromatogram has the same number and nature of the peaks as those described in the literature, there is only a difference in the values of the retention time compared with the published data [22] due to differences in the alkyl vaccination silica, as C4 type column was used instead of C8.

In order to determine the molecular weight of the obtained surfactant protein an analysis of extracts by disc electrophoresis method was conducted. As a control, insulin was used $(\mathrm{M}=6 \mathrm{kDa})$. The results of electrophoresis are shown in Figure 4.

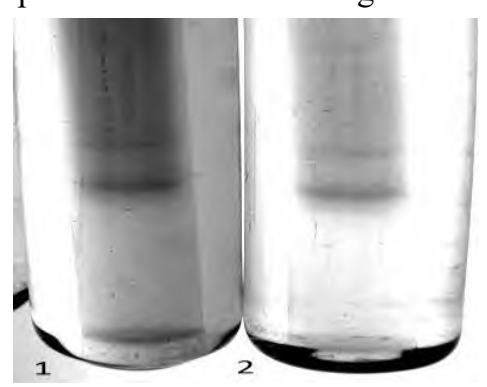

1 - studied extract, 2 - control (insulin).

Fig. 4. Disc electrophoresis in PAAG of protein extracted from Coprinus lagopides biomass.

It was determined that the molecular weight of the protein contained in the extract, corresponding approximately to a known from the literature molecular weight of hydrophobins, (7-14 kDa). 
It is known that the presence of hydrophobins in the foamed solution even at very low concentrations, enables very high foam stability. To estimate the surface activity of the obtained extracts their foam-stabilizing ability was tested. The sodium caseinate was used as a control for comparison. The volume of the resulting foam was measured one hour after foaming and further for 2 months every week. The results are shown in Figure 5.

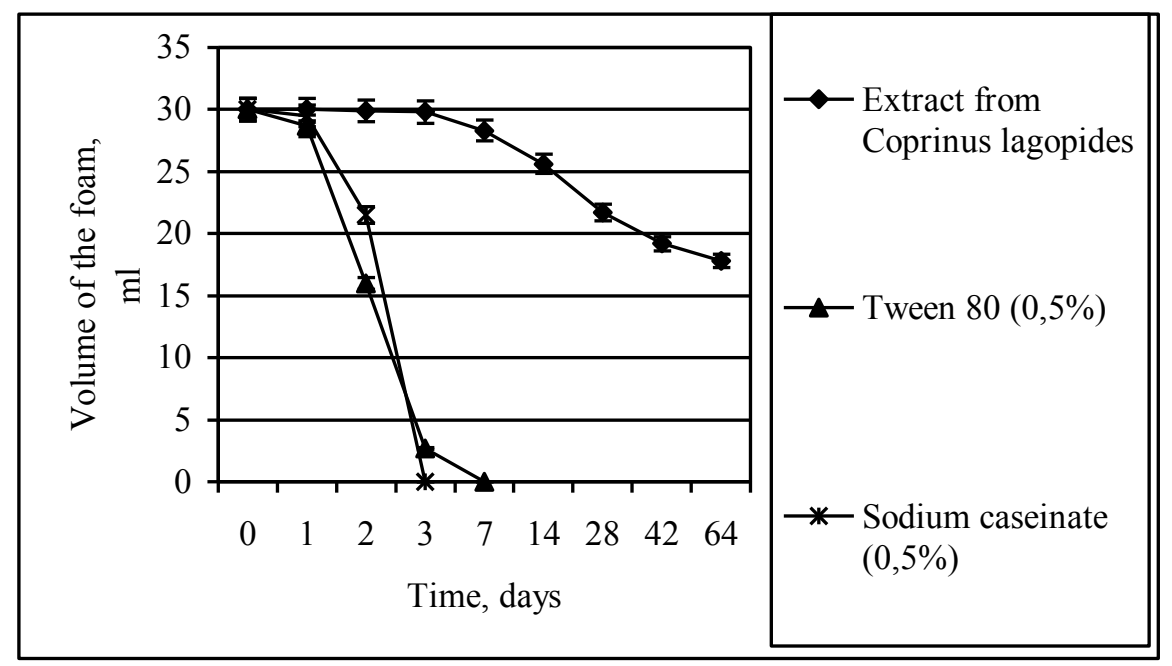

Fig. 5. The volume of the foam stabilized extract from Coprinus lagopides mushroom mycelia biomass.

The diagram shows that the extracts allow to obtain stable foams. Air phase losses in the samples with addition of extract were about $50 \%$ at 8 weeks, while in the control sample with sodium caseinate there was a complete loss of air phase after 2 weeks. The results indicate that the properties of the foam-stabilizing surfactant protein were significantly higher than those of sodium caseinate, commonly used in manufacturing.

To obtain a dry preparation of milk-clotting enzyme native solution of culture liquid obtained by cultivating of Coprinus lagopides on a medium number 11, for purification and concentration of enzyme was subjected to sequential ultrafiltration and than freeze dried. Material balance of the process is presented in Table 6 .

As a result of concentration, purification and subsequent drying a powder of dry enzyme preparation with a high level of MCA, as well as a high ratio of MCA to PA levels was obtained. Enzyme preparation obtained from the native solution of culture liquid provides the thick milk clot without bitterness.

\section{Conclusion}

As a result of carried out experiments, it was determined that the studied mushroom Coprinus lagopides is a novel promising source of surfactant proteins and milk-clotting enzymes. Obtained protein extracts have high foam-stabilizing ability not inferior to industrial foam stabilizers. Enzyme preparation obtained from the native solution of culture liquid provides the thick milk clot without bitterness, and has a high ratio of MCA to the PA.

The proposed integrated method for producing and isolating of a surfactant protein and milk-clotting enzyme can significantly reduce the cost of production and simultaneously receive two valuable products as a result of a single fermentation. 


\section{References}

1. L.V. Garibova, S.N. Lekomtseva, Bases of Mycology: Morphology and systematics of fungi and fungi-like organisms (Textbook, T-scientific publications in KMK, Moscow, 2005)

2. J.G.H. Wessels, O.M.H. de Vries, S.A. Ásgeirsdóttir, F.H.J. Schuren, Hydrophobin genes involved in formation of aerial hyphae and fruit bodies in Schizophyllum commune, Plant Cell 3, 793-799 (1991)

3. A.R. Cox, D.L. Aldred, A.B. Russell, Exceptional stability of food foams using class II hydrophobin HFBII, Food Hydrocolloids 23 (2), 366-376 (2009)

4. S.O. Lumsdon, J. Green, B. Stieglitz, Adsorption of hydrophobin proteins at hydrophobic and hydrophilic interfaces, Colloids and Surfaces B: Biointerfaces 44, 172-178 (2005)

5. F.L. Tchuenbou-Magaia, I.T. Norton, P.W. Cox, Hydrophobins stabilised air-filled emulsions for the food industry, Food Hydrocolloids 23, 1877-1885 (2009)

6. M. Sunde, A.H. Kwan, M.D. Templeton, R.E. Beever, J.P. Mackay, Structural analysis of hydrophobins, Micron 39 (7), 773-784 (2008)

7. O.M.H. de Vries, M.P. Fekkes, H.A.B. Wösten, J.G.H. Wessels, Insoluble hydrophobin complexes in the walls of Schizophyllum commune and other filamentous fungi, Arch. Microbiol. 159, 330-335 (1993)

8. J.G.H. Wessels, Hydrophobins, proteins that change the nature of the fungal surface, Adv. Microbial Physiol. 38, 1-45 (1997)

9. M. Amaha, K. Kitabatake, A. Nakagava, J. Yoshida, T. Harada, Gushing inducers produced by some moulds strans, In: Proc Eur Brew Conv 14th Congress, Salzburg, 381-398 (1973)

10. M.I. Janssen, M.B. van Leeuwen, T.G. van Kooten, J. de Vries, L. Dijkhuizen, H.A. Wösten, Promotion of fibroblast activity by coating with hydrophobins in the b-sheet end state, Biomaterials 25, 2731-2739 (2004)

11. M.I. Janssen, M.B. van Leeuwen, K. Scholtmeijer, T.G. van Kooten, L. Dijkhuizen, H.A. Wösten, Coating with genetic engineered hydrophobin promotes growth of fibroblasts on a hydrophobic solid, Biomaterials 23, 4847-4854 (2002)

12. K. Scholtmeijer, M.I. Janssen, B. Gerssen, M.L. de Vocht, B.M. van Leeuwen, T.G. van Kooten, H.A. Wösten, J.G. Wessels, Surface modifications created by using engineered hydrophobins, Appl. Environ. Microbiol. 68, 1367-1373 (2002)

13. Y. Corvis, A. Walcarius, R. Rink, N.T. Mrabet, E. Rogalska, Preparing catalytic surfaces for sensing applications by immobilizing enzymes via hydrophobin layers, Anal. Chem. 77, 1622-1630 (2005)

14. Z.X. Zhao, M.Q. Qiao, F. Yin, B. Shao, B.Y. Wu, Y.Y. Wang, X.S. Wang, X. Qin, S. Li, Q. Chen, Amperometric glucose biosensor based on self-assembly hydrophobin with high efficiency of enzyme utilization, Biosens. Bioelectron. 22, 3021-3027 (2007)

15. A.J. Green, K.A. Littlejohn, P. Hooley, P.W. Cox, Formation and stability of food foams and aerated emulsions: Hydrophobins as novel functional ingredients 18 (4), 292-30 (2013)

16. M. Shamtsyan, T. Dmitriyeva, B. Kolesnikov, N. Denisova, Novel milk-clotting enzyme produced by Coprinus lagopides basidial mushroom, LWT - Food Science and Technology 58 (2), 343-347 (2014) 
17. M. Shamtsyan, Potential to develop functional food products from mushroom bioactive compounds, Journal of Hygienic Engineering and Design 15, $51-59$ (2016)

18. N.R. Draper, H. Smith, Applied Regression Analysis, 3rd ed. Wiley-Interscience, New York (1998)

19. A.J. Richard, W.W. Dean, Applied multivariate statistical analysis (Prentice-Hall, London, 2002)

20. L. Wang, D. Ridgway, T. Gu, M. Moo-Young, Bioprocessing strategies to improve heterologous protein production in filamentous fungal fermentations, Biotechnology Advances 23, 115 - 129 (2005)

21. Practicum on Microbiology, ed. N.S. Yegoeova, (Moscow state university, Moscow, 1976)

22. O.M.H. de Vries, M.P. Fekkes, H.A.B. Wiisten, J.G.H. Wessels, Insoluble hydrophobin complexes in the walls of Schizophyllum commune and other filamentous fungi, Arch Microbiol. 159, 330-335 (1992)

23. O.M.H.de Vries, S. Moore, C. Arntz, J.G.H. Wessels, P. Tudzynski, Identification and characterization of a tri-partite hydrophobin from Claviceps fusiformis, A novel type of class II hydrophobin, Eur. J. Biochem, 262, 377-385 (1999)

24. A. Armenante, Pleurotus ostreatus hydrophobins: surface active proteins. Dottorato in Scienze Biotecnologiche - XXI ciclo, Indirizzo Biotecnologie Industriali, Università di Napoli Federico II (2008)

25. S.A. Ásgeirsdóttir, J.R. Halsall, L.A. Casselton, Expression of Two Closely Linked Hydrophobin Genes of Coprinus cinereus Is Monokaryon-Specific and DownRegulated by the oid-1 Mutation, Fungal Genetics and Biology. 22, 54-63 (1997)

26. S. Askolin, Characterisation of Trichoderma reesei hydrophobins HFBI and HFBII. DSc thesis Helsinki University of Technology (2006)

27. O.H. Lowry, N.J. Rosebrough, A.L. Farr, R.J. Randall, Protein measurement with the Folin phenol reagent, The Journal of Biological Chemistry 193, 265-275 (1952)

28. U.K. Laemmli, Cleavage of Structural Proteins during the Assembly of the Head of Bacteriophage T4, Nature 227, 680-685 (1970)

29. M. Kawai, N. Mukai, Studies of milk-clotting enzymes produced by Basidiomycetes, Part I. Screening test of basidiomycetes for the production of milk-clotting enzymes, Agricultural and Biological Chemistry 34(2), 159-163 (1970) 